\title{
REMOTE MILANO
}

Teatro em zona de experiência compartilhada

Resumo: O propósito desta comunicação é instaurar um espaço de reflexão sobre as mudanças ocorridas nas práticas cênicas contemporâneas, por meio da análise da obra de audiotour Remote Milano do coletivo suíçoalemão Rimini Protokoll - prática que dialoga com temática e sujeitos reais em espaços reais da cidade. Comunico minha experiência enquanto espectadora-participante do referido audiotour, dando ênfase ao meu papel de artista-pesquisadora, como uma maneira de evidenciar a impossibilidade de negar minha presença no contexto da pesquisa pelo viés da expectação, da experimentação, da análise, ou seja, por um olhar no contexto em que a obra foi experimentada. Apresento assim, uma concepção sobre «teatro em zona de experiência compartilhada» que se justifica como presença efêmera, em total relação com a realidade social, desconstruindo as hierarquias tradicionais do teatro, que evidencia a existência de um teatro fora da instituição-Teatro, fora de um teatro do texto, fora do teatro do ator que conta uma história, ao mesmo tempo, que abre fendas para que o espectador torne-se sujeito da experiência. Como método uso aporte teórico de publicações italianas, espanholas e brasileiras - produzidas recentemente sobre o tema, descrição e registros pessoais coletados ao longo da pesquisa em torno do objeto de estudo. Resultando no entendimento de que a experiência com Remote Milano se trata de experiência viva, que relaciona a ficção e o real no aqui e agora e coloca o sujeito da experiência em total produção de presença na relação espacial com o mundo e os seus objetos.

Palavras-chave: Rimini Protokoll. Experiência compartilhada. Produção de presença. Real e ficção.

Abstract: The purpose of this communication is to create a space for reflection on the changes that have occurred in contemporary scenic practices, through the analysis of the work of audiotour Remote Milano of the Swiss-German collective Rimini Protokoll - a practice that dialogues with themes and real subjects in real spaces of the city. I communicate my experience as a spectatorparticipant of this audiotour, emphasizing my role as an artist-researcher, as a way of highlighting the impossibility of denying my presence in the context of the research through the bias of expectation, experimentation, analysis, in other words, looking from inside the context in which the work was experienced. Therefore, I present a conception of "theater in a zone of shared experience" that justifies itself as an ephemeral presence, in total relation with social reality, deconstructing the traditional hierarchies of the theater, which evidences the existence of a theater outside the TheaterInstitution, outside of a theater of the text, outside the theater of the actor, that tells a story, at the same time that it opens up cracks so that the spectator becomes also the subject of the experience. As a method I use the theoretical contribution of Italian, Spanish and Brazilian publications - 
recently produced on the subject, description and personal records collected throughout the research around the object of study. Resulting in the understanding that the experience with Remote Milano is a living experience that relates fiction and reality in the here and now and places the subject of the experience in total production of presence in the spatial relation with the world and its objects.

Keywords: Remote Milano. Rimini Protokoll. Shared experience. Production of presence.

\section{INTRODUÇÃO:}

Analiso o teatro em zona de experiência compartilhada no espaço-tempo urbano, para além da hierarquia dos elementos teatrais presentes no teatro convencional, por meio da minha experiência de espectadora, no ano de 2014, no audiotour intitulado «Remote Milano» criado por Stefan Kaegi membro do coletivo alemão Rimini Protokoll.

O interesse pela temática está ligado com a diluição das fronteiras entre arte e vida, real e ficção, concepções de ser e está no mundo. As vozes de alguns interlocutores tornam-se pertinente neste trabalho porque abriram «portas» para melhor falar da experiência de ser e estar no mundo. As portas, aqui, abertas por mim são as que me levam a viver, observar e encarar o mundo real.

A reflexão da prática cênica, no contexto da cidade, se coaduna com percepções de mundo. Dessa maneira, busco falar a partir daquilo que nos envolve, nos toca, nos acontece por meio da experiência teatral viva, num encontro entre espectador-participante, como testemunha de uma cena no aqui-agora do cotidiano urbano.

Nas contribuições de Gumbrecht (2010), possibilidades de dar saltos, em termos de teoria e prática, almeja não somente ao estudo e à pesquisa, mas à consciência de ser e estar no mundo. Acreditando num mundo que produz discursos «atravessados», ou seja, para além das «paredes do teatro» e de uma arte «protegida» - parafraseando Paulo Freire, no processo prático e teórico do teatro deve-se: dissolver a «submissão do discurso temporal» em «experiências compartilhadas»; continuar brincando de mesclar real e ficção - sendo consciente do seu estado de presença - de quando se observa e quando se é observado e o que se observa.

Portanto, apresentarei uma reflexão sobre as relações e os movimentos que são estabelecidos entre a experiência com Remote Milano, em sua prática teatral que interfere no espaço cotidiano da cidade e como essas práticas teatrais dialogam com a cidade e resulta numa nova relação entre o evento cênico e o espectador-participante.

\section{REFERENCIAL TEÓRICO:}

Remote Milano é um teatro em zona de experiência compartilhada, já que possibilita ao espectador participante, criar em torno do que já havia sido criado, dando a este um adjetivo de co-criador da 
obra. Mas esse só se torna co-criador porque a obra transforma-se em experiência de crise de percepcao ou desestabilidade perceptiva (Erika Fischer-Lichte, 2013).

Alguns teóricos vêm criando prolegômenos em torno da discussão, a exemplo: “teatro postdrammatico ou teatro performativo”. José Sánchez, (2007), esclarece que: “aquelas propostas a respeito das quais cabe o comentário: 'já não é teatro', de fato, poderia não 'já não ser teatro', mas é arte, produção simbólica, comunicação responsável ${ }^{1}$.

Fala-se também sobre a "noção de perda de uma comunidade determinada pelo pressuposto de que o teatro deve se opor ao individualismo da indústria cultural”. (Fischer-Lichte, 2014). Flávio Desgranges (2011), através da ótica de Rancière - observa que a "emancipação intelectual" do espectador, lhe conduz a diferentes leituras da obra.

Desse modo, produção de presença “(...) refere-se, em primeiro lugar, às coisas [res extensae] que, estando a nossa frente, ocupam espaço, são tangíveis aos nossos corpos e não são apreensíveis, exclusiva e necessariamente, por uma relação de sentido”. Então, presença diz respeito “à relação espacial com o mundo e os seus objetos”. O observador/a na "produção de presença” é aquele que não está imbuído da intencionalidade de sentido, mas de presença córporea, mesmo que a presença não ocorra apenas na pura materialidade. Na prática teatral contemporânea, pode se converter em gestos simbólicos.

\section{METODOLOGIA:}

Os dados referentes a este trabalho resultam de minha dissertação de mestrado: "O teatro do agora: percepção e presença para além das fronteiras do espetáculo”, (2016). Bem como, por meio de uma pesquisa bibliográfica, que tem como interlocutores: Fischer-Lichte(2014); Gumbrecht, (2010); Lehmann(2007); Sánchez (2009); Fernandes(2011), Bondía (2002); e Desgranges (2011). E de registros pessoais coletados durante e após a experiência vivenciada no audiotour Remote Milano.

\section{CONSIDERAÇÕES:}

A partir da experiência no Remote Milão, 50 espectadores movem-se no espaço urbano em grupo. A ação de caminhar juntos cria um ambiente que favorece uma experiência de caráter comunitário temporário, onde o espectador torna-se ativo no ato de criar em torno do que já havia sido criado, dando ao evento cênico um estado de re-criação.

1 Sáchez Revista Camarim, 2007, p.5. 
Stefan Kaegi acredita que “é melhor assistir a cena da sociedade ali onde elas se passam, do que representálas com atores maquiados”2. Portanto são práticas autênticas, presenciais e efêmeras que se inter-relacionam com o mundo em tempo real.

O espaço da cidade é o local de cruzamento de criatividade e de encontro entre artistas e não artistas, portanto, a experiência com o audiotour Remote Milano é um organismo vivo, em constante movimento e que nos permite falar que estas práticas cênicas são respostas a essa sensação de “perda de mundo” ou perda do passado. (Gumbrecht, 2010).

\section{REFERÊNCIAS:}

BONDÍA, Jorge L. Notas sobre a experiência e o saber de experiência. Rivista Brasileira de Educação, n.19. Campinas: Universidade Estadual de Campinas, 2002.

CABALLERO, Ileana D. Escenarios liminales. Teatralidades, performatividades y políticas, $2^{\mathrm{a}}$ ed., México, Paso de Gato, 2014.

FERNANDES, Silvia. Teatralidades Contemporâneas, (Estudos 277 / Dirigida Por J. Guinsburg) São Paulo: Perspectiva, 2010.

FISCHER-LICHTE, E. Estetica del performativo. Una teoria del teatro e dell'arte. Roma: Carocci editore. (Tradução de Tancredi Gusman e Simona Paparelli), 2014.

GUMBRECHT, Hans U. Produção de Presença: o que o sentido não consegue Transmitir. (tradução de Ana Isabel Soares), Rio de Janeiro, Contraponto, 2010.

RANCIÈRE, J. O espectador emancipado. (Tradução de Ivone C. Benedetti). São Paulo: Editora WMF Martins Fontes, 2012.

2 Roth-Lange, Freidheim. De quem é o palco? Revista do instituto Goethe, Humboldt, dez/2011, p.30 